\title{
PUTATIVE AMPLIFICATION OF 16S rRNA MARKERS OF ESCHERICHIA COLI AND SALMONELLA SPP ISOLATES FROM DRINKING WATER IN SAKI
}

\author{
*ADEOTI O. M ${ }^{1}$, IDOWU T. A ${ }^{2}$, OLAOYE O. J. ${ }^{3}$, OLUFEMI S. O ${ }^{4}$, ADESINA ${ }^{5}$ \& ADEOYE K. A $^{\mathbf{6}}$ \\ ${ }_{1,3,4,5,6}$ Research Scholar, Department of Science Laboratory Technology, Microbiology Option, The Oke- Ogun Polytechnic \\ Saki, Oyo State Nigeria
}

${ }^{2}$ Graduate Student, Department of Pure \& Applied Biology, Microbiology Option P. M. B. 4000, Ladoke Akintola University of Technology, Ogbomoso, Oyo State, Nigeria

${ }^{6}$ Research Scholar, Department of Zoology, Parasitology Unit, University of Ibadan, Ibadan Nigeria

${ }^{5}$ Research Scholar, Department of Microbiology \& Botany, University of Ibadan, Nigeria

${ }^{1}$ Research Scholar, Department of Zoology, Cellular Parasitology Unit, University of Ibadan, Nigeria

\begin{abstract}
A systematic random sampling of eight water samples was collected early in the morning in some selected area of Saki. The physico-chemical, total viable count, total coliform counts and molecular amplification of the isolates DNA from borehole and well water were analysed. Subsequently, the isolates were subjected to colonial morphological appearance on agar media and biochemical tests before sensitivity was carried against different eight negative antibiotics. The DNA of the isolates was extracted and subsequent amplification of vital genes was performed using PCR techniques. A more specific primers for Salmonella and E. coli was used for the amplification of the 16S rRNA genes by Sanger sequencing techniques. The resultant nucleotides sequences was blasted for comparative homology with similar genes in the GenBank. The total viable bacteria count of isolates ranged from $0.82 \times 10^{5} \mathrm{cfu} / \mathrm{ml}$ (WAT) to $2.82 \times 10^{5} \mathrm{cfu} / \mathrm{ml}(\mathrm{WAG})$, while Total coliform count was from $0.25 \times 10^{5} \mathrm{cfu} / \mathrm{ml}$ to $1.76 \times 10^{5} \mathrm{cfu} / \mathrm{ml}(\mathrm{BOA})$. Both counts were significant at (P> 0.05). The level of contamination of the selected water sources were contaminated by $79 \%$ E.coli, and $70 \%$ Salmonella spp. Other pathogenic isolates such as Shigella, Klebsiella spp, Staphylococcus, Enterobacter spp, Pseudomonas spp and Proteus spp. Antibiotic susceptibility showed that Salmonella spp and Escherichia coli were resistant to multiple antibiotics except Ofloxacin and Ceftriaxone. However, molecular analysis confirmed the presence of vital genes, as probably, responsible for multiple drug resistance in E.coli and Salmonella strains. These genes which was amplified at $1.5 \mathrm{~kb}$ were detected in the samples at $80 \%$ and $70 \%$ occurrence in Salmonella and E. coli respectively.
\end{abstract}

KEYWORDS: Physicochemical Properties, Coliform, Total Bacteria Count, Amplification, Primers \& 16S rRNA

Received: May 01, 2020; Accepted: May 22, 2020; Published: Jun 11, 2020; Paper Id.: IJBRDJUN20204

\section{INTRODUCTION}

Water being a universal gift of nature is a constituent of two atoms of chemical element and one atom of gas in a ratio of (2:1) binded by covalent bonds. Therefore, the chemical formula is binary compound. It is shaped by the direct reaction of chemical element with gas [1]. Oceans hold ninetyseven (97\%) percent of surface water, ice mass and polar ice cap a pair of $0.4 \%$ and alternative land surface water like rivers, lakes and ponds zero $(6 \%)$ [2]. Water used for human consumption is termed as drinking or moveable water [3] and such water is used for different activities with no risk of exploiting any water borne diseases. Access to safe potable water has enhanced steadily and considerably for the past many years virtually in some area of the world [4]. One to seven litres of water per day is mostly useful for functioning body system to circumvent dehydration 
[5, 6]. Accessibility to safe water and gross domestic product, per capita are correlated. However, research has revealed that almost half of the globe population are going to be facing water-based vulnerability by 2025 [7]. Man can survive for twenty-eight (28) days without food, however solely three (3) days without water, and two third of water consumption per day is through food, whereas one third is obtained through drinking [1]. Typically, water has been recognised to be a sustaining medium for life; however researches have revealed that water not only enhances the quality of life but also may function as carrier of precarious pathogens [3]. However, unsafe water majorly serves as link for transmission of water related to pathogenic diseases and therefore the significance of water on health cannot be overemphasized publically. Public mostly, find it difficult to differentiate between safe water and moveable water thereby enhancing their chance of susceptibility to health problem which are unremarkably as a result of drinking unsafe water. In several cases, there are unfavourable environmental conditions area; for example, defecating within the near bushes, proximity of wells from latrines, the consequences of oil exploration and exploitation within the zone plus the direct biodegradable pollution - contamination of natural water bodies due to the cultural habit of defecating within rivers, practiced in Niger Delta Regions of Nigeria have contributed greatly to pollution [8]. Epidemic cholera natural event has been rumoured in African country, Bharat and Nigeria that was caused by the presence of eubacteria cholerae in municipal faucets and wells [9], eightieth of sicknesses and deaths among youngsters worldwide are related to the consumption of unsafe water [10]. Additionally, the occurrence of eubacteria cholerae (cholera), and alternative gram-negative microorganism like enteric bacteria entenritidis (gastroenteritis), Escherichia (gastroenteritis), enteric dysenteriae responsible for (dysentery) and salmonella causing typhoid fever is of municipal health distress. Other area of concern are that boreholes typically provide pure water initially and afterwards if the water is not properly maintained, it could become unsafe for drinking, due to increased presence of present microorganism. Enzyme chain reaction (PCR) is among the foremost usually employed molecular method for detecting waterborne pathogens [11, 12]. Many disparity of PCR like multiplex PCR (mPCR) allow synchronal discovery of many target microorganisms by writing precise genes of various pathogens within the sample in an exceedingly single reaction. PCR technique has the benefit of rapid testing [13].

\section{METHODS}

\subsection{Study site and Sampling Techniques}

The research was carried out in Saki, Saki West Local Government area of Oyo State, Nigeria. It is located between 8.67 latitude and 3.39 longitudes. It is situated at elevation of 427 meters above sea level. Saki has a population of 178,677 people, making it the $3^{\text {rd }}$ biggest city in Oyo State.

\subsection{Sample Collection}

A total number of eight (8) samples were randomly collected from various sites within the study location with the use of $200 \mathrm{ml}$ pre-sterilized sample bottles with lid cover. Water samples $(200 \mathrm{mls})$ were collected from different borehole and well water sources using sterile water collection, which was labelled as (BOA, BOF, WAG, WAS, WAC, WAF, WAW, WAT) from the various boreholes and wells following a method described by [14], with slight modification.

\subsubsection{Physico-Chemical Analysis}

Parameters such as Total Dissolved Solids (TDS in $\mathrm{mg} / \mathrm{L}$ ), temperature $\left({ }^{\circ} \mathrm{C}\right), \mathrm{pH}$ and conductivity were analysed in water samples from the two water sources by standard methods [7]. 


\section{$2.3 \mathrm{pH}$ Determination}

Multi-functional $\mathrm{pH}$ meter (Pancellent water Quality meter) was employed to examine the $\mathrm{pH}$ of the collected water samples. Calibrated $\mathrm{pH}$ meter with standard solutions of $(\mathrm{pH} 4.0,7.0$, and 10.0) was used for the measurement and readings were taken for samples after the $\mathrm{PH}$ probe insertion into the water samples and it was then allowed to stay for minutes to ensure reading stabilization. Precautions of crossed contamination of different samples were avoided through the wash of the probe with deionized water after each sample measurement.

\subsection{Bacteriological Quality Determination Total Bacteria Count}

Each of the water samples was serially diluted on a ten-fold dilution. Exactly $1 \mathrm{ml}$ of a $10^{-3}$ dilution and $10^{-5}$ each of the samples was introduced into a prepared nutrient medium using pour plate technique. This was properly swirl to maintain uniformity, bacteria lawn was allowed to set and then incubated at $37^{\circ} \mathrm{C}$ for 24 hours. The resultant colonies formed were counted and result expressed as cfu/ml by using electric colony counter.

\subsubsection{Presumptive Coliform Test}

The presumptive coliform analysis was determined in accordance with the standard technique of [14, 15]. Here, different quantity of water sample were added in double and single strength. MacConkey broth in sterile tubes as follows:3 $\times 10 \mathrm{ml}$ water sample to $5 \mathrm{ml}$ double strength medium, $3 \times 1 \mathrm{ml}$ water sample to $3 \mathrm{ml}$ single strength medium and $3 \times 0.1 \mathrm{ml}$ water sample to $3 \mathrm{ml}$ single strength medium. The tubes were incubated at $37^{\circ} \mathrm{C}$ for 24 hours. These were later examined for production of acid and gas. Sterile distilled water was used as a negative control for each test batch. Presumptive coliform count was obtained by the multiple tube techniques of coliform per $100 \mathrm{ml}$ of water sample by making reference to similar study [14].

\subsubsection{Identification of the Isolates}

All sample organisms were Gram stained and observed under microscope. Analysis on Biochemical examination was evaluated based on Gram reactions and the following tests such as oxidase, sugar fermentation (glucose, maltose sucrose, and lactose), indole, citrate, and catalase were determined. [16] Disc diffusion method was adopted for the antimicrobial susceptibility test on Mueller-Hinton Agar medium.

\subsection{Molecular Sequencing analysis}

The bacteria that were picked to create antibiogram were streaked on to nutrient agar slants to make sample cultures and for DNA extraction and PCR analysis.

\subsubsection{Bacteria DNA Extraction (Cell Lysis)}

To extract the DNA of the test organisms, $300 \mu \mathrm{l}$ of cell Lysis solution was introduced into a clean and sterile $2 \mathrm{ml}$ Eppendorf tube as earlier illustrated by [17], single or two clean colonies of the bacteria samples was scraped using the tip of the pipette and was transferred into the Eppendorf tube and then was thoroughly mixed to lyse the cells. $2 \mu$ l of lysozyme was then added into the Eppendorf tube and then incubated at $55^{\circ} \mathrm{C}$ for 60 minutes.

\subsubsection{Protein Precipitation}

Protein precipitation solution of $100 \mu \mathrm{l}$ was mixed into the cell lysate and was shaken rigorously for 20 seconds to mix well and was then centrifuged at maximum speed for $2 \mathrm{~min}$. The resulting precipitated proteins form a light dark pellet 
which was incubated on frost for 5 minutes and then centrifuged again.

\subsubsection{DNA Precipitation}

$300 \mu \mathrm{l}$ of $99 \%$ Isopropanol solution was introduced into a clean $2 \mathrm{ml}$ Eppendorf tube and the supernatant from the protein precipitation was mixed with it by inverting gently for 1 minutes. The mixture was centrifuged at maximum speed for 1 minutes DNA became visible as a small white pellet. The supernatant was discarded and the tube was drained briefly on clean absorbent paper. $500 \mu \mathrm{l}$ of Washing Buffer was added and the tube was inverted several times to wash the DNA pellet. The DNA pellet was centrifuged at maximum speed for 1 minutes and the ethanol was carefully discarded and dried at room temperature for about 10 to 15 minutes.

\subsubsection{PCR Protocol}

The PCR was carried out to amplify the 16S rRNA as determined by the use of specific type primers 27F

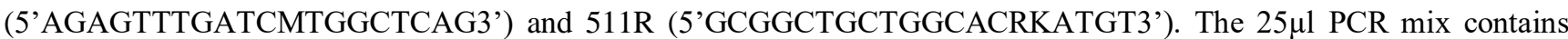
$5 \mu \mathrm{l}$ of $5 \mathrm{x}$ PCR mix by Jena Bioscience (Jena Germany). $1 \mu \mathrm{l}$ each of the primers, $13 \mu \mathrm{l}$ of PCR grade water and $5 \mu \mathrm{l}$ of the template (bacteria DNA). The PCR program included one denaturing step at $95^{\circ} \mathrm{C}$ for 3 minutes, 25 cycles of $95^{\circ} \mathrm{C}$ for 40 seconds, $55^{\circ} \mathrm{C}$ for 40 seconds and $72^{\circ} \mathrm{C}$ for 40 seconds followed by final extension at $72^{\circ} \mathrm{C}$ for 7 minutes. Gel electrophoresis was used to check the existence of a single band in an expected size for each PCR product. A $2 \%$ agarose gel was used and this was passed across an electric field with 100 volts.

2.5.5 Statistical analysis: Experiments were performed in triplicate. Data were presented as mean and the means were compared by Posthoc Ducan's New Multiple Range test at $\alpha<0.05$. Data were also analysed by one-way Analysis Of Variance (ANOVA) and differences were considered significant at $(\mathrm{P}<0.05)$.

\section{RESULTS}

The Physico-Chemical analysis from borehole and well water in the area, Saki Oyo is shown in Table1. There are statistical differences $(\mathrm{p}<0.05)$ in the different physicochemical parameters that were monitored. There were no notable differences observed for colour and odour for the different water samples assessed. The $\mathrm{pH}$ of water samples from boreholes and well sources was significantly different $(P<0.05)$. No differences $(P>0.05)$ was observed in the $\mathrm{pH}$ level of sample collected from BOA (6.27) and that of BOF and WAC but was different from samples from other water sources monitored in this study. Also pH 6.47, 6.60 and 6.09 observed in water samples from BOF, WAC and WAT, respectively were also similar but significantly lower than 7.20, 7.77, 8.80 and 8.70 observed in WAF, WAW, WAG and WAS, respectively. Temperature of water samples from this study however ranged from 25.10- 27.57. Values for $\mathrm{pH}$ however ranged from 6.27 (BOA) to 8.80 (WAG). There was slight differences in the temperature $\left({ }^{\circ} \mathrm{C}\right.$ ) of water samples from BOA (26.03), BOF (25.80), WAS (26.00) and WAW $\left(26.03^{\mathrm{c}}\right)$ but statistically differ $(\mathrm{P}<0.05)$ from other water samples while temperature of water samples taken from WAC (25.10) and WAT (25.23) showed no significant difference $(\mathrm{P}>0.05)$. Temperature of water samples from this study however ranged from (25.10- 27.57). TDS (mg/l) was significantly different across the different water samples analysed. Value ranged from WAW (96.3) to WAS (270.0). Conductivity (uscm-1) was significantly different across the different water samples analysed. Value ranged from WAG (216) to WAC (530.0). 
Salmonella SPP Isolates from Drinking Water in Saki

Table 1: Physicochemical Parameters of Water Samples in selected Area in Saki

\begin{tabular}{|c|c|c|c|c|c|c|c|c|c|}
\hline Parameters & BOA & BOF & WAC & WAF & WAG & WAS & WAT & WAW & SEM \\
\hline Colour (Hazen Unit) & 0.00 & 0.00 & 0.00 & 0.00 & 0.00 & 0.00 & 0.00 & 0.00 & 0.00 \\
\hline Odour & A & A & A & A & A & A & A. & A & A \\
\hline pH & $6.27^{\mathrm{e}}$ & $6.47 d^{\mathrm{e}}$ & $6.60^{\mathrm{de}}$ & $7.20^{\mathrm{c}}$ & $8.80^{\mathrm{a}}$ & $8.70^{\mathrm{a}}$ & $6.90^{\mathrm{cd}}$ & $7.77^{\mathrm{b}}$ & 0.20 \\
\hline Temperature ( $\left.^{\mathbf{0}} \mathbf{C}\right)$ & $26.03^{\mathrm{c}}$ & $25.80^{\mathrm{c}}$ & $25.10^{\mathrm{d}}$ & $26.97^{\mathrm{b}}$ & $27.57^{\mathrm{a}}$ & $26.00^{\mathrm{c}}$ & $25.23^{\mathrm{d}}$ & $26.03^{\mathrm{c}}$ & 0.16 \\
\hline TDS(mg/l) $^{\text {Conductivity }}$ & $156.6^{\mathrm{d}}$ & $260.0^{\mathrm{a}}$ & $140.0^{\mathrm{e}}$ & $172.3^{\mathrm{c}}$ & $210.0^{\mathrm{d}}$ & $270.0^{\mathrm{a}}$ & $110.0^{\mathrm{f}}$ & $96.3^{\mathrm{f}}$ & 12.72 \\
\hline $\begin{array}{c}\text { (uscm-1) } \\
\text { (usce }\end{array}$ & $355.0^{\mathrm{d}}$ & $256.6^{\mathrm{e}}$ & $530.0^{\mathrm{a}}$ & $416.6^{\mathrm{c}}$ & $216.6^{\mathrm{f}}$ & $360.0^{\mathrm{d}}$ & $243.3^{\mathrm{e}}$ & $476.6^{\mathrm{b}}$ & 22.27 \\
\hline
\end{tabular}

Note: $\mathrm{A}=$ Acceptable; TDS = Total Dissolved Solid; $(\mathrm{mg} / \mathrm{l}) . \mathrm{BOF}=$ Borehole water 1, BOA = Borehole Water 2 , WAC = Well water 1, WAF $=$ Well water 2, WAG $=$ Well water 3, WAS $=$ Well water 4, WAT $=$ Well water 5, WAW = Well water 6, SEM = Standard error of mean. Superscript (a, b, c, d, e and f) means with similar superscript across the same row are not significant.

Table 2: Bacteriological Analysis of Borehole and Well Water in selected Area in Saki

\begin{tabular}{|c|c|c|}
\hline Water Samples & $\begin{array}{l}\text { Total Bacteria Count } \\
(\mathrm{CFU} / \mathrm{ml}) \times 10^{5}\end{array}$ & $\begin{array}{l}\text { Total Coliform Count } \\
\quad(\mathrm{CFU} / \mathrm{ml}) \times 10^{5}\end{array}$ \\
\hline BOF & $1.43^{\mathrm{d}}$ & $0.84^{\mathrm{f}}$ \\
\hline BOA & $1.92^{\mathrm{b}}$ & $1.76^{\mathrm{b}}$ \\
\hline WAC & $1.43^{\mathrm{d}}$ & $1.45^{\mathrm{c}}$ \\
\hline WAF & $1.22^{\mathrm{e}}$ & $0.75^{\mathrm{g}}$ \\
\hline WAG & $2.82^{\mathrm{a}}$ & $2.25^{\mathrm{a}}$ \\
\hline WAS & $1.61^{\mathrm{c}}$ & $1.03^{\mathrm{d}}$ \\
\hline WAT & $0.82^{\mathrm{f}}$ & $0.53^{\mathrm{h}}$ \\
\hline WAW & $1.45^{\mathrm{d}}$ & $0.93^{\mathrm{e}}$ \\
\hline SEM & 0.006 & 0.11 \\
\hline
\end{tabular}

SEM = Standard error of mean. Superscript (a, b, c, d, e and f) means with similar superscript across the same row are not significant. $\mathrm{BOF}=$ Borehole water $1, \mathrm{BOA}=$ Borehole water $2, \mathrm{WAC}=$ Well water $1, \mathrm{WAF}=$ Well water $2, \mathrm{WAG}=$ Well water 3 , WAS $=$ Well water 4 , WAT $=$ Well water 5 and WAW $=$ Well water 6.

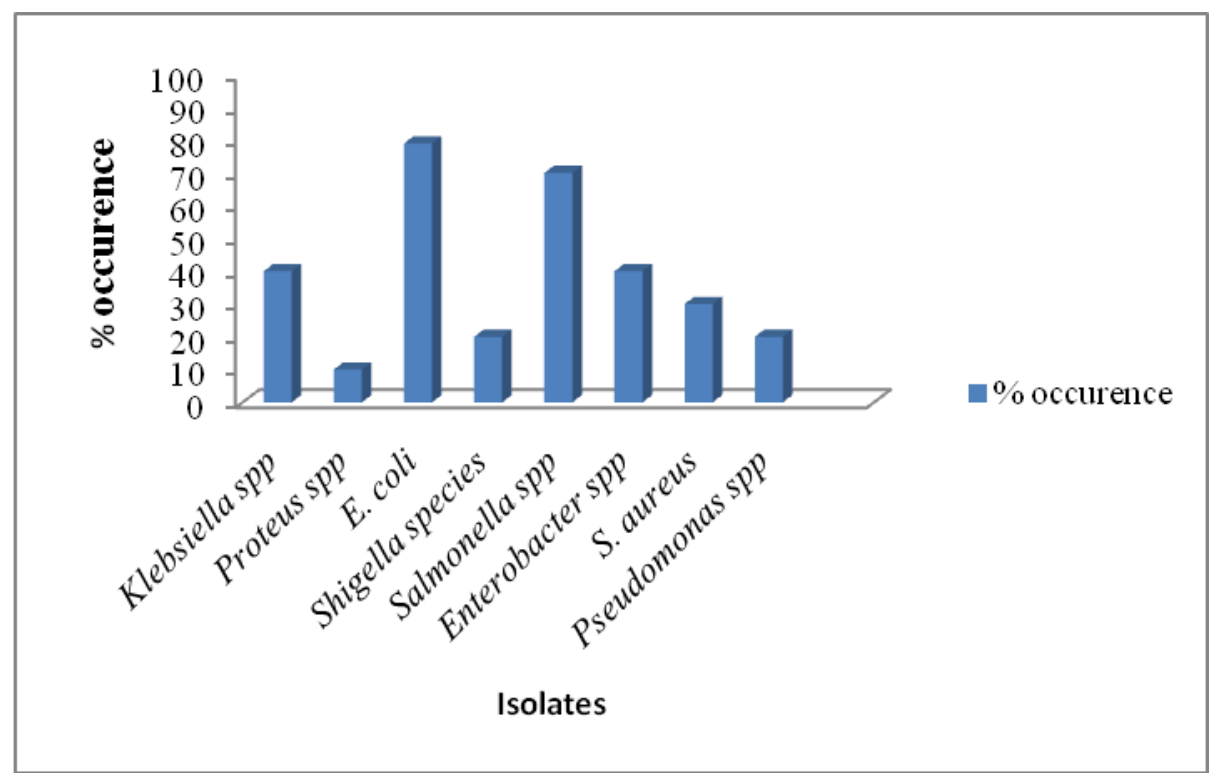

Figure 1: Percentage Occurrence of the Isolate in Well Water and Borehole Sample. 
Table 3: Biochemical Tests used for Suspected Bacterial Isolates

\begin{tabular}{|c|c|c|c|c|c|c|}
\hline Test & $\begin{array}{c}\text { Klebsiella } \\
\text { Species }\end{array}$ & $\begin{array}{c}\text { Shigella } \\
\text { species }\end{array}$ & $\begin{array}{c}\text { Escherichia } \\
\text { coli }\end{array}$ & $\begin{array}{c}\text { Enterobacter } \\
\text { species }\end{array}$ & $\begin{array}{c}\text { Staphylococcus } \\
\text { aureus }\end{array}$ & $\begin{array}{c}\text { Salmonella } \\
\text { species }\end{array}$ \\
\hline Indole & - & - & + & - & + & - \\
\hline Catalase & + & + & + & + & + & + \\
\hline Oxidase & - & - & - & - & - & - \\
\hline Citrate & + & - & - & + & + & - \\
\hline Lactose & + & - & + & + & + & - \\
\hline Glucose & + & + & + & + & + & + \\
\hline Maltose & + & + & + & + & + & + \\
\hline Sucrose & + & - & + & + & + \\
\hline
\end{tabular}

Positive (+) Negative (-)

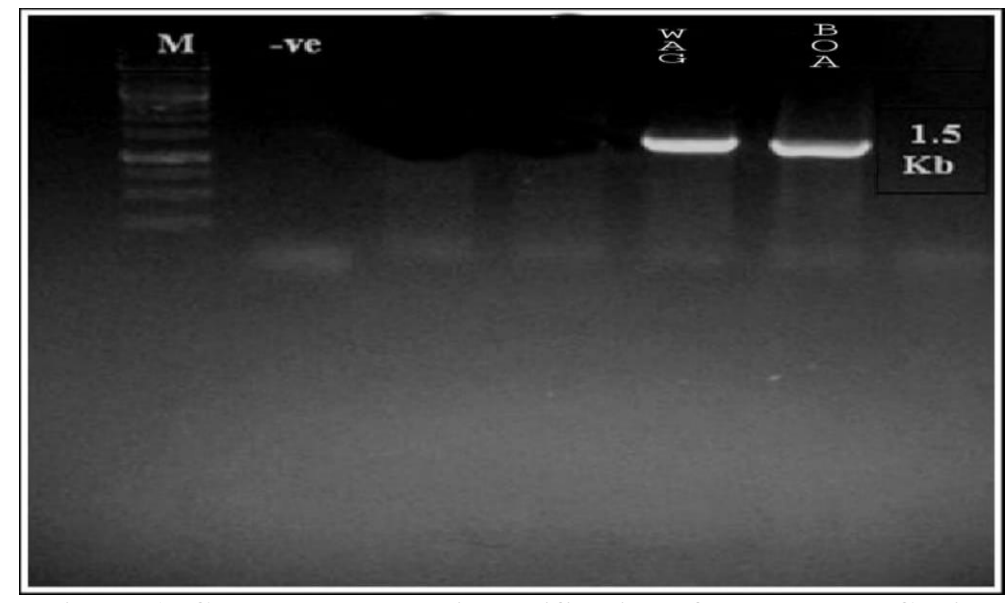

Figure 1: Gel Electrophoresis Purification of Polymerase Chain Reaction Amplicons of Representative's Bacteria Isolates from Borehole and Water Samples (WAG \& BOA) using and Salmonella species and Escherichia coli type Specific Primers.

\section{DISCUSSIONS}

\subsection{Physicochemical Characteristics of Water Samples}

Based on the physical analysis carried out on the samples, the comparative analytical results of borehole water and well water samples are shown in Figure 1. The outcome of the analysis showed that the odours of all the borehole water are not detected and the entire colours are within the safe range recommended for safe drinking water by the standard of the WHO.

\subsubsection{Odour}

The results of analysis showed that odour of all the borehole water are undetectable and the entire colours are within the safe limit recommended for drinking water by standard of the WHO. The result of this study is similar to [18]. It showed that odour was not perceived in the water samples used for the analysis.

\subsubsection{Colours}

The results of analyses showed colour of all the borehole and well water are between the safe ranges recommended for drinking water by WHO Standard. The result of this study is similar to [18]. It showed that colour was not observed in the water samples used for the analysis. 


\subsection{3 pH}

$\mathrm{pH}$ is defined as the acidity or alkalinity condition of a solution. The $\mathrm{pH}$ of the investigated water samples revealed slight alkalinity, with values ranging from (6.27-8.80). This showed slight increase compared to WHO and NSDWQ acceptable rang of 6.5-8.5. Long -term exposure to $\mathrm{pH}$ above the acceptable range affects the mucous membrane of cells. This $\mathrm{pH}$ result is similar to [17]. Whose $\mathrm{pH}$ results ranged from 6.02 and 9.96 .

\subsubsection{Temperature}

Temperature is regarded as a predominant factor that could influence bacterial growth. In an atmosphere where there is high water temperature, it can result in rapid bacterial growth; however, the least temperature required for microbial growth activity varies from system to system (WHO 2003). As shown in this study, high temperature values were recorded for most of water well and borehole water samples, temperature ranged from $25.10-27.60^{\circ} \mathrm{C}$., the recorded temperature values were all beyond the WHO acceptable limits of $\left(25^{\circ} \mathrm{C}\right)$ for quality drinking water.

\subsubsection{Total Dissolved Solid (TDS)}

Total Dissolved Solid values recorded for this analysis was within $500 \mathrm{mg} / \mathrm{dm}^{3}$ range for all water samples which are conformed to WHO recommendation. The values ranged from $\left(96.3-270 \mathrm{mg} / \mathrm{dm}^{3}\right)$. This result was similar to [18]. They recorded the TDS values which are within the WHO standard, ranged from the lowest value, 69.7 to $360 \mathrm{mg} / \mathrm{dm}^{3}$.

\subsubsection{Electrical Conductivity (EC)}

The movement of ions in solution is regarded to be similar to the total alkalinity. It isn't new that the flow of water would be relative to the hydroxide ion (alkalinity) concentration in the water. The analyses show electrical conductivity in water samples are within the WHO guide of $1000(\mu \mathrm{scm}-1)$. The electrical conductivity in well water in the study area has values ranged from (216.6-530.0) $\mu \mathrm{scm}$-1. Electrical conductivity in well water is noted to be lower in the wet season [19].

\subsection{Bacteriological Analysis}

\subsubsection{Total Bacteria Count}

The analysis of the Total Bacteria count in all sources of water samples showed the appearance of heterotrophic bacteria in all the water sources (Table 2). The recommendation of WHO for heterotrophic bacteria in a potable water assert that the total count of heterotrophic bacteria should exceed $100 \mathrm{cfu} / \mathrm{ml}$ [20]. If bacteria count doesn't conform to the standard, this shows that there is presence of bacteria in such water sample that wouldn't make it suitable for drinking and domestic purposes. The Total Bacteria count from this study exceeded WHO limits. This research reported that, the total viable bacterial count varying from $0.82 \times 10^{5} \mathrm{cfu} / \mathrm{ml}$ to $2.82 \times 10^{5} \mathrm{cfu} / \mathrm{ml}$ said to higher above the standard range of $<500 \mathrm{cfu} / \mathrm{ml}$. This observation is related to the study of [21].

\subsubsection{The Total Coliform}

The total coliform count of the well and Borehole water sample used in this finding ranged from $0.25 \times 105 \mathrm{cfu} / \mathrm{ml}$ to $1.76 \times 105 \mathrm{cfu} / \mathrm{ml}$. These results are slightly elevated when compared with the acceptable MPN index by World Health Organization of 10 coliform $/ 100 \mathrm{ml}$ of water sample. This finding is in consonance with the observation of [18, 22], who accounted for high coliform counts in all well and borehole water analysed. The high number of total coliform could be due to inadequate maintenance of the well water as many of the wells are uncovered. It can also be attributed to percolation 
of sewage into the ground water sources [12]. The well water and borehole water in the present study were highly contaminated with one or more of the following bacteria, Staphylococcus aureus, Escherichia coli, Proteus species, Salmonella species, Enterobacter species, Klebsiella species, Pseudomonas species and Enterococcus species. Majority of these microorganisms are prospective pathogens of the coliform group which are member of Enterobacteriacea. A related finding has been documented by [18]. Who revealed the incidence of Klebsiella species, Enterobacter species, Escherichia coli and Proteus spp in most of the well water samples which makes them unsafe for human consumption [23].

\subsubsection{Biochemical test, Colonial and Morphological Characteristics}

The following bacteria which include Pseudomonas aeruginosa, Klebsiella spp, Proteus spp, Salmonella spp, Enterococcus spp, Proteus spp, Staphylococcus aureus, Shigella spp, and Escherichia coli were isolated from borehole and well waters, as given in Table 4. Escherichia coli appeared as $a$ bright pink colonies on MacConkey agar with a moist glistening growth Salmonella appeared as a colourless, transparent, smooth and raised colonies on MacConkey agar while On Eosin Methylene Blue (EMB) agar, E. coli strains displayed its characteristic greenish metallic sheen colonies.

\subsubsection{Antibiotic Sensitivity Tests}

Antibiotic sensitivity tests were performed for each of the eight identified bacterial species. The Antibiotic Sensitivity Pattern of the isolates were tested against antibiotic discs with concentration of the drug as Augmentin (AUG, $30 \mu \mathrm{g}$ ),

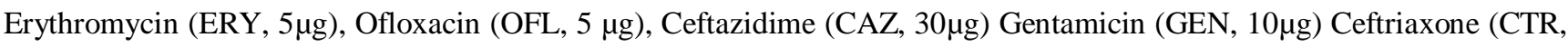
$30 \mu \mathrm{g})$ and Cefuroxime (CRX, $30 \mu \mathrm{g}$ ), Cloxacillin (CXC, 5 $\mu \mathrm{g}$ ). The Antibiotic Sensitivity Pattern was determined by comparing the zones of inhibition (measured in $\mathrm{mm}$ ) with the reference chart as Sensitive, Intermediate and Resistant.

\subsubsection{Molecular Characterization of E.coli and Salmonella}

Genomic DNA and amplification of 16S rRNA gene by PCR technique using E.coli and Salmonella species specific primers, which gives a positive result. Real-time PCR techniques are used for their improved sensitivity and specificity. Many PCR-based process are available for the discovery of Salmonella and E.coli by amplifying various targets genes such as stx, eae, fimA, rfbE, etc. The results of the PCR technique revealed that the specific gene targets ( 1 (stx 1$)$, shigatoxin 2 (stx 2), intimin (eaeA) genes, InVA and stn genes of Salmonella spp and E. coli. were detected in eight water samples with \% occurrence of (80\%), and (70\%), respectively. This showed highest presence of water contamination. The PCR technique had a higher precision for the discovery of these bacteria in water samples. Molecular characterization of the E.coli isolates for virulent genes indicated the presence of shiga toxin 1 (stx 1), shigatoxin 2 (stx 2$)$ and intimin (eaeA) genes. This finding revealed that the PCR techniques were highly precise, safe and faster than culture methods. The existence of E. coli and Salmonella spp in drinking water is hazardous to human well-being. These bacteria can be responsible for diarrhea, abdominal cramps, vomiting, fever, nausea and haemorrhagic colitis [24]. Several serotype groups can result to a transitory enteric infection like gastroenteritis with diarrhea in susceptible individuals. However, certain serotypes can leads to non-symptomatic infection [25]. The Salmonella spp and E. coli are cosmopolitan, therefore infected humans and animals through sewage, soil, and even aquaculture can be eventual sources of water bacterial contamination, and this current research firstly reported the discovery of E. coli, Salmonella spp in borehole and well water in Saki. Poor obedience to the laws guiding water purification and treatment in the borehole and well water in Saki may contribute to a greater extent in subjecting drinking water to become unsafe for consumption. The reported prevalence of enteric bacteria in drinking water is one of the major reports. The outcome of this research revealed that this water is contaminated, and 
strict compliance is needed to rectify these challenges. According to guideline from the WHO (World Health Organization), CAWST (Centre for Affordable Water and Sanitation Technology) and previous studies, drinking water must be free from E. coli and Salmonella spp [26]. The bacteriological examination of the well water samples in the present study showed a high level of bacteria load. The coliform count exceeded the acceptable limits which render the water unsafe for consumption and cleaning. The suggestion of contamination in borehole and well water is primarily result from lack of attention given to the construction and safety of this source of water by the entire populace [27]. Also, bacteria found from the different sample are majorly of enteric organisms which are potential pathogens which call for community health alert. Hence, there is necessity for proper water maintenance, environmental hygiene around the well areas and cleanliness practices by the households and individuals need to help in decreasing the menace of disease outbreak that could generate due to the organisms encountered in this finding. The characterization of organism by the molecular technique16SrRNA sequencing is specific and reliable method. It is carried out by first isolating the Genomic DNA then amplifying the 16SrRNAgene by PCR technique. In addition, use of PCR techniques gives a precise, safe, sensitive, specific, and rapid diagnostic technique which could be adopted to follow-up the microbial load of drinking water.

\section{REFERENCES}

1. Bhat, T. A., (2014). An analysis of demand and supply of water in India. Journal of Environmental and Earth Science. 4(11), 67-73.

2. Adesogan, S. O., (2014). Strategies and techniques of providing adequate and affordable portable water in rural areas of Nigeria. International Journal of Water Resources and Environmental Engineering, 6(1), 32-39.

3. Oyedum, M. U. (2010). Occurrence of faecal coliform contamination of well and borehole water. A project thesis presented to the Department of Microbiology, Federal University of Technology Minna, Niger State. 6 pp.

4. APHA, Standard Methods for the Examination of Water and Wastewater, American Public Health Association, Washington, DC, USA, 2014

5. Okonkwo, T. J., Okorie, O., and Okonkwo, C. J., (2011). Public Health Risk Status of the Water Supply Frame Work at Kwame Nkrumah (Postgraduate) Hall, University of Nigeria, Nsukka and Environment. African Journal of Environmental Science and Technology, Vol. 5(7), pp. 522-529.

6. Mbaenyi. I. E., and Egbuche, N., I. (2012). Microbiological evaluation of sachet water and street vendored Yoghurt and Zobo drinks sold in Nsukka Metropolis. International Journal of Bio-chemical. Science 6(4): 1703-1717

7. Taiwo, O. B., Obadofin, S. T., and Ajayi, O. J., (2015). Groundwater quality assessment in Akungba-Akoko, Ondo State. Nigeria. Research Journal of Environmental and Earth Sciences. 7(1), 9-14.

8. Wokem, G. N., and Lawson, J. T., (2014). Microbiological Quality of Domestic Water Sources in Abonnema Community. Journal of Aquatic Science 29, (2B): 391 - 400.

9. Sur, D., Sarka, B. L., Dean, J., Delta, S., and Niyogi, S. K., (2006). Epidemiological, microbiological and electron microscopic study of a cholera outbreak in a Kolkata slum community. Indian Journal of Medical Res 123: 31-36.

10. WHO (2003). World health organization. Safe Piped Water: managing microbial water quality in piped distribution systems. Geneva. 5 pp.

11. Law, J. W., Mutalib, N. S., Chan, K. G., and Lee, L. H., (2014). Rapid methods for the detection of foodborne bacterial pathogens: Principles, applications, advantages and limitations. Front. Microbiology 5, 770. 
12. Gambo J. B., James, Y., Yakubu, M. B., (2015). Physico Chemical and Bacteriological Analysis of Well Water at Crescent Road Poly Quarters, Kaduna. International Journal of Engineering and Science, 4 (11): 11-17.

13. Zhao, S., Tyson, G. H., Chen, Y., Li, C., Mukherjee, S., Young, S., Lam, C., Folster, J. P., Whichard, J. M., McDermott, P. F., (2016). Whole - genome sequencing analysis accurately predicts antimicrobial resistance phenotypes in Campylobacter spp. Applied Environmental Microbiology 82:459 -466.

14. Mackie, J. T., McCartney J. E (1989). Practical Medical Microbiology, In: College, J. C. Dugluid, J. P. Frasor, A. G. and Marmion, B. P. Eds., Church Living Stone Publication, $p 910$.

15. Ngwa, N. R., and Chrysanthus, N. (2013). Bacteriological Analysis of Well Water Sources in the Bambui Student Residential Area. Journal of Water Resource and Protection, 5, 1013- 1017.

16. Bauer, A. W., Kirby, W. M., Sherris, J. C., and Turck, M., (1996). Antibiotic susceptibility testing by a standardized single disk methods. Journal of clinical pathology. April; 45(4):493-6.

17. Ramadan TB, Danielsen M, Valina O, Garrigues C, Johansen E and Pedersen MB (2016) Streptococcus thermophilus core genome: comparative genome hybridization study of 47 strains. Appl Environ Microbiol 74: 4703-4710.

18. Istifanus, Y., Chindo, E. K., and Ephraim, D., and Amanki,. (2013). Physicochemical Analysis of Ground Water of Selected Areas of Dass and Ganjuwa Local Government Areas, Bauchi State, Nigeria." World Journal of Analytical Chemistry 1, no. 4 (73-79).

19. Olubanjo, O. O., (2018). Effects of heavy metals dumping on soil, water and plant within Akure, Ondo State. International Journal of Development Research. 08(07), 21430-21436.

20. World Health Organization (2006). Protecting Groundwater for Health: Managing the Quality of Drinking Water Sources. IWAPublishing, London

21. Agwaranze, D. I., Ogodo, A. C., Nwaneri, C. B., and Agyo, P., (2017). Bacteriological Examination of Well Water in Wukari, Nigeria. International Journal of Scientific Research in Environmental Science, 5 (2): 42-46.

22. Gambo, J. B., James, Y., Yakubu, M. B., (2015). Physico Chemical and Bacteriological Analysis of Well Water at Crescent Road Poly Quarters, Kaduna. International Journal of Engineering and Science, 4 (11): 11-17.

23. WHO (1996). Guidelines for Drinking Water Quality: Health Criteria and Other Support Information. World Health Organization, pp. 18-97.

24. Ocepek, M., Pate, M., Kušar, D., Hubad, B., Avberšek, J., Logar, K., Lapanje, A., and Zrimec, A., (2011). Comparison of DNA extraction methods to detect Salmonella spp. in tap water. SloveniaVeterinary Research, 48:93-98.

25. Maier, R. M., Pepper, I. L., Gerba, C. P.,( 2000). Environmental Microbiology. Academic Press, San Diego, CA.

26. World Health Organization WHO (2011). Guidelines for drinking-water quality. Edition. Switzerland: WHO Library Cataloguing-in-Publication.

27. Obafemi, Y. D., Ajayi, A. A., Taiwo, O. S., Olorunsola, S. J., and Isigbor, P. O., (2019). Isolation of PolygalacturonaseProducing Bacterial Strain from Tomatoes (Lycopersiconesculentum Mill.). International Journal of Microbiology. Volume 2019, Article ID 7505606.

28. Ehigie Leonard Ona, Okonji Raphael Emuebie, Folashade Adeola, Ehigie Adeoye Akinwunmi Oluwaseun, and Falode John Adeolu, "Properties of Thiaminase in Freshwater Prawn Machrobrachium rosenbergii", IMPACT: International Journal of Research in Applied, Natural and Social Sciences (IMPACT: IJRANSS), Vol. 3, Issue 4, pp. 37-48 
29. Belay Tafa Oba, “Assessment of Physicochemical Properties of Water From Lake Chamo”, International Journal of Applied and Natural Sciences (IJANS), Vol. 6, Issue 1, pp. 69-76

30. J. Lopez, W. R. Aguirre-Contreras, M. E. Gómez \& G. Zambrano, "Zn Concentration Influence on the Structure, Morphology and Magnetic Properties of Co (1-X) Znxfe2o4 Nanoparticles in Ferrofluids", International Journal of Applied and Natural Sciences (IJANS), Vol. 6, Issue 2, pp. 47-60

31. Bhavna Tripathi\& Rajlakshmi Tripathi, "Effect of Wheat Bran Incorporation on Physicochemical Properties of Sweet and Salty Biscuits", International Journal of Agricultural Science and Research (IJASR), Vol. 8, Issue 3, pp. 119-126 

